\title{
Targeted Proteomics Approach to Species-Level Identification of Bacillus thuringiensis Spores by AP-MALDI-MS
}

\author{
Jennifer Nguyen and Scott C. Russell \\ Department of Chemistry, California State University, Stanislaus, Turlock, California, USA
}

\begin{abstract}
Anthrax infections progress at a rapid pace, making rapid detection methods of utmost importance. MALDI-MS proteomics methods focused on Bacillus anthracis detection have targeted chromosomally encoded proteins, which are highly conserved between closely related species, hindering species identification. Presented here is an AP-MALDI-MS method targeting plasmid-borne proteins from Bacillus spores for species-level identification. A bioinformatics analysis revealed that $60.3 \%$ and $75.4 \%$ of tryptic peptides from plasmid-borne proteins of $B$. anthracis and $B$. thuringiensis were species-specific, respectively. Reported here is a method in which plasmid-borne $\delta$-endotoxins were extracted directly from B. thuringiensis spores in $100 \mathrm{mM} \mathrm{KOH}$. The $\mathrm{pH}$ was then adjusted to 8 and a 5 -min trypsin digestion was performed on the extracted proteins. The resulting tryptic peptides were analyzed by AP-MALDI-MS/MS, which produced a definitive identification the B. thuringiensis speciesspecific Cry1 Ab protein with a MASCOT score of 278 and expect value of $7.5 \times 10^{-23}$. This method has demonstrated the detection and identification of $B$. thuringiensis spores at the species level following a 5-min trypsin digestion. The challenges in applying a similar approach to the detection of plasmid-borne protein toxins from B. anthracis are also discussed. (J Am Soc Mass Spectrom 2010, 21, 993-1001) (C 2010 American Society for Mass Spectrometry
\end{abstract}

$B$ acillus anthracis, the causative agent of anthrax, has been categorized as a "class A agent" by the center for disease control and prevention (CDC) [1]. This classification states that $B$. anthracis poses a significant threat to human health [1]. The spore form of $B$. anthracis is extremely rugged and can handle severe environmental conditions, which makes it an optimum delivery vehicle for biowarfare applications. Sadly, $B$. anthracis has already been used with lethal effects. In 1979, the Soviet military covered up an "accidental" release that ended up killing 64 people [2]. In 1993, the terrorist group, Aum Shinrikyo, attempted to release $B$. anthracis over a Japanese city [3]. Fortunately, the strain that was released was not fully virulent [3]. The most recent event occurred in 2001, in which B. anthracis was sent through the U.S. mail and resulted in five deaths [4]. Unfortunately, in each of these cases, it took days to weeks to discover that exposure had occurred [2-4]. Obviously, this amount of time for detection is unsatisfactory for effective treatment of those exposed. Consequently, a rapid method for the detection of $B$. anthracis is desperately needed.

Many techniques have been explored as methods for rapid microorganism detection. The requisites for an

Address reprint requests to Dr. S. C. Russell, Department of Chemistry, California State University, Stanislaus, Naraghi Hall of Science, One University Way, Turlock, CA 95382-0299, USA. E-mail: srussell@chem. csustan.edu effective method are specificity, sensitivity, selectivity, and speed. Two promising techniques, real-time PCR and mass spectrometry, target genetic information at different levels: DNA and proteins. The polymerase chain reaction (PCR) has demonstrated unparalleled levels of sensitivity and specificity by targeting DNA for amplification [5-7]. Unfortunately, the time required for the PCR reaction hinders rapid detection [5-7].

Both electrospray (ESI) and matrix-assisted laser desorption/ionization (MALDI) have been applied to microorganism identification [8-13]. However, ESI is prone to clogging and produces complicated spectra with multiple charge states, making filtering and fractionation necessary before mass analysis of proteins from microorganisms [8-10].

Matrix-assisted laser desorption/ionization mass spectrometry (MALDI-MS) has emerged as a promising alternative to PCR due to its high sensitivity and detection times ranging from seconds to minutes [1113]. MALDI-MS can be applied to microorganism identification by detecting proteins expressed by the microorganism, but the proteins must be species-specific. However, the level of specificity of MALDI-MS techniques has been limited by extremely high amino acid sequence conservation of chromosomally encoded proteins between closely related species [13-15]. This problem is extremely prevalent for $B$. anthracis due to a high abundance of closely related species (B. thuringiensis 
and B. cereus) in the environment. Fortunately, these species harbor different plasmids that encode entirely different protein toxins [16]. These plasmid-borne protein toxins provide attractive analytical targets for species-level identification. B. cereus produces protein toxins that cause stomach illness [17]. B. anthracis produces three protein toxins that cause the symptoms of anthrax [18]. B. thuringiensis produces $\delta$ endotoxins that target receptors in the stomachs of many insects [19].

Reported here is a proof-of-concept study demonstrating species-level identification of $B$. thuringiensis spores by AP-MALDI-MS by targeting plasmid-borne $\delta$-endotoxins. These protein toxins were targeted for detection due to their degree of specificity to the $B$. thuringiensis species. AP-MALDI offers the advantage of reduced in-source fragmentation compared with conventional MALDI, which can reduce spectral complexity [20-23]. B. thuringiensis was used as a model organism due to its close genetic similarity to $B$. anthracis [16]. This species also poses no threat to humans and is readily available as an organic pesticide under the trade name Dipel-DF [24]. In addition, detecting the toxins provided confirmation that the bacterium is virulent. The $\delta$-endotoxins produced by B. thuringiensis were used as biomarkers for the $B$. thuringiensis microorganism. Robust biomarkers are abundant enough for detection and specific to the phenotype of interest, which is species identification in this case. The $B$. thuringiensis endotoxins are produced in high relative abundance and have also been reported to be highly specific to $B$. thuringiensis [25]. These two properties make them attractive analytical targets.

Obviously the species of greatest interest is B. anthra$c i s$, not $B$. thuringiensis. The toxins produced by each species are high molecular weight proteins $(>70 \mathrm{kDa})$ that are encoded on plasmids. However, adapting this approach to $B$. anthracis would require addressing several challenges in addition to requiring access to a Biosafety level 3 facility. Detection of the B. anthracis toxins would likely require germination to the vegetative cell state before analysis. Germination has been demonstrated in as little as $15 \mathrm{~min}$ by heat activation for $10 \mathrm{~min}$ and suspension in media containing $60 \mathrm{mM}$ dipicolinic acid and $60 \mathrm{mM} \mathrm{CaCl} 2$ for 5 min [26]. Induction of toxin expression would also be required and has been demonstrated in media containing $48 \mathrm{mM}$ bicarbonate, which has been found to induce expression and secretion of protective antigen at levels of 20 $\mu \mathrm{g} / \mathrm{mL}[27,28]$. The secretion of protective antigen is advantageous, as cell lysis would not be required to detect the protein toxin. It should also be pointed out that the method to rapidly detect $B$. thuringiensis $\delta$-endotoxins would be inherently useful and applicable to the agricultural/biotech community, such as quickly monitoring $B$. thuringiensis corn for $\delta$-endotoxin presence.

\section{Experimental}

\section{Bioinformatics}

Five plasmid encoded $\delta$-endotoxins of Bacillus thuringiensis var. kurstaki: Cry1Aa, Cry1Ab, Cry1Ac, Cry2Aa, $\mathrm{Cry} 2 \mathrm{Ab}$ were digested with trypsin in silico with no missed cleavages allowed. The three plasmid encoded protein toxins of B. anthracis (lethal factor, edema factor, and protective antigen) were also digested with trypsin in silico with no missed cleavages allowed. The resulting tryptic peptides were searched against the Swiss-Prot/ TrEMBL database for exact sequence matches using the MS-BLAST platform [29]. Each peptide was categorized as being unique to its respective protein, unique to its species, unique to both, or neither.

\section{Source and Treatment of B. thuringiensis Spores}

The source of $B$. thuringiensis was the commercially available organic bio-pesticide Dipel-DF. This pesticide contains Bacillus thuringiensis var. kurstaki HD-1, which is reported to produce five high molecular weight protein toxins (Cry1Aa, Cry1Ab, Cry1Ac, Cry2Aa, and Cry $2 \mathrm{Ab}$ ) [24]. The spores were washed in deionized water before analysis by 1D gel electrophoresis. However, the spores were not washed at all before performing the rapid digestion method. Although these bacteria are found throughout the natural environment and do not pose a human threat, they were handled according to nationally recognized biosafety standards at all times [30].

\section{Optimization of $\delta$-Endotoxin Solubilization}

It has been documented extensively in the literature that $B$. thuringiensis $\delta$-endotoxin solubilization requires alkaline conditions $[19,31]$. To find an optimum $\mathrm{pH}$ for efficient $\delta$-endotoxin solubilization, $10 \mathrm{mg}$ samples of the crude $B$. thuringiensis spores were suspended in 1 $\mathrm{mL}$ solutions covering a $\mathrm{pH}$ range $8-13$, vortexed for $60 \mathrm{~s}$ and centrifuged at $10,000 \times g$ for $20 \mathrm{~min}$. The supernatants were then filtered through $0.45 \mu \mathrm{m}$ filters. Each supernatant was then loaded onto a 7.5\% Tris-HCl 1D gel for an evaluation of solubilization efficiency based on $\delta$-endotoxin protein content. Additionally, $65 \mathrm{mM}$ DTT was evaluated over the same $\mathrm{pH}$ range with respect to improving $\delta$-endotoxin solubilization efficiency.

\section{$\delta$-Endotoxin Stability at Reduced $p H$}

To perform a trypsin digestion, the $\mathrm{pH}$ must be adjusted to a range 7.5-9. Concern regarding $\delta$-endotoxin protein stability/solubility was evaluated by performing a solubilization at $\mathrm{pH}=13$ by suspending $B$. thuringiensis spores at $10 \mathrm{mg} / \mathrm{mL}$ in $100 \mathrm{mM} \mathrm{KOH}$. Aliquots of the $\delta$-endotoxin extract solution were subsequently titrated to $\mathrm{pH}$ values of $7,8,9,10,11$, or 12 
with $100 \mathrm{mM} \mathrm{HCl}$. Each of these solutions was visually evaluated for precipitation formation and none was observed. Each fraction was further evaluated for $\delta$-endotoxin protein content by sodium dodecyl sulfate polyacrylamide gel electrophoresis (SDS-PAGE) [32, 33].

\section{SDS-PAGE: Screening for Efficient $\delta$-Endotoxin Extraction}

Protein extracts were mixed 1:1 by volume with 710 $\mathrm{mM} \beta$-mercaptoethanol in Laemmli sample buffer and boiled for $10 \mathrm{~min}$; $30 \mu \mathrm{L}$ aliquots of each extract were loaded onto a $7.5 \%$ Criterion Tris- $\mathrm{HCl}$ Gel (Biorad, Hercules, CA, USA); $30 \mu \mathrm{L}$ of precision plus protein standards (Biorad) were also loaded as a molecular weight reference. Running buffer consisting of $25 \mathrm{mM}$ Tris, $192 \mathrm{mM}$ Glycine, and 0.1\% SDS was used. The gel was run at a constant voltage of $200 \mathrm{~V}$, fixed in $40 \%$ methanol, $10 \%$ acetic acid, stained for $1 \mathrm{~h}$ with BioSafe Coomassie blue (Biorad), and destained $3 \times$ with DI water. Gels were imaged with a HP (Palo Alto, CA, USA) Photosmart C4280 document scanner.

\section{In-Gel Trypsin Digestions}

Protein bands at $\sim 70 \mathrm{kDa}$ and $\sim 130 \mathrm{kDa}$ were excised from the $7.5 \%$ Tris- $\mathrm{HCl}$ gel and digested according to a protocol based largely on that of Rosenfeld et al. [34]. Spots were destained two times in $200 \mu \mathrm{L}$ of $50 \%$ acetonitrile, $25 \mathrm{mM} \mathrm{NH} \mathrm{NCO}_{3}$ at $37^{\circ} \mathrm{C}$ for $30 \mathrm{~min}$. Proteins were reduced in $30 \mu \mathrm{L}$ of $50 \mathrm{mM}$ tris(2carboxyethyl)phosphine, $25 \mathrm{mM} \mathrm{NH}_{4} \mathrm{HCO}_{3}$ at $60{ }^{\circ} \mathrm{C}$ for $10 \mathrm{~min}$, and alkylated in $30 \mu \mathrm{L}$ of $100 \mathrm{mM}$ iodoacetamide, $25 \mathrm{mM} \mathrm{NH}_{4} \mathrm{HCO}_{3}$ in the dark at room temperature for $1 \mathrm{~h}$. Gels pieces were then shrunk with $50 \mu \mathrm{L}$ of acetonitrile for $15 \mathrm{~min}$ at room temperature. The acetonitrile was removed and gel pieces were allowed to air dry. Gels were swelled in $35 \mu \mathrm{L}$ of $25 \mathrm{mM}$ $\mathrm{NH}_{4} \mathrm{HCO}_{3}$ containing $100 \mathrm{ng}$ of activated trypsin (Thermo Fisher Scientific, Rockford, IL, USA). Digestions were allowed to proceed overnight at $30{ }^{\circ} \mathrm{C}$ with gentle shaking. The resulting tryptic digest peptides were cleaned up with $\mu \mathrm{C}-18$ Ziptips (Millipore, Billerica, MA, USA) and spotted directly on the APMALDI plate for tandem MS analysis.

\section{Rapid $\delta$-Endotoxin Extraction and In-Solution Digestion}

B. thuringiensis spore suspensions were prepared at 10 $\mathrm{mg} / \mathrm{mL}$ in $100 \mathrm{mM} \mathrm{KOH}(\mathrm{pH}=13)$, vortexed for $1 \mathrm{~min}$, and allowed to sit for an additional $19 \mathrm{~min}$ to ensure $\delta$-endotoxin solubilization. The $\mathrm{pH}$ of the $\delta$-endotoxin solution was then adjusted to 8 with drop-wise addition of $1 \mathrm{M} \mathrm{HCl}$. A $100 \mu \mathrm{L}$ aliquot of a $50 \%$ by mass suspension of immobilized trypsin (Thermo Fisher Scientific, Rockford, IL, USA) in $100 \mathrm{mM} \mathrm{NH}_{4} \mathrm{HCO}_{3}$ was added to a $100 \mu \mathrm{L}$ aliquot of the $\delta$-endotoxin solution. It was estimated based on known $\delta$-endotoxin expression levels from $B$. thuringiensis var. kurstaki HD-1 that $\sim 50$ $\mu \mathrm{g}$ of total $\delta$-endotoxin proteins were present in the digestion mixture $[35,36]$. The enzymatic digestion was performed for $5 \mathrm{~min}$ at room temperature [13]. Immobilized trypsin was used to avoid trypsin autolysis [37]. No reduction and alkylation was performed to keep the analysis time to a minimum. Digestions were quenched upon centrifugation at $10,000 \times g$ for $3 \mathrm{~min}$ to remove the spores, and immobilized trypsin. A $10 \mu \mathrm{L}$ aliquot of the supernatant was then cleaned up and concentrated to $5 \mu \mathrm{L}$ via a $\mu \mathrm{C}-18$ Ziptip, and spotted on the APMALDI plate for tandem MS analysis.

\section{AP-MALDI-MS}

Briefly, $1 \mu \mathrm{L}$ of the tryptic digest was spotted, followed by $1 \mu \mathrm{L}$ of $\alpha$-cyano-4-hydroxycinnamic acid at 10 $\mathrm{mg} / \mathrm{mL}$ in $70 \% \mathrm{ACN}$ and $0.1 \%$ TFA. All samples were analyzed with an LTQ linear ion trap (Thermo Fisher Scientific, San Jose, CA, USA) equipped with an atmospheric pressure matrix-assisted laser desorption/ ionization source (Masstech, Columbia, MD, USA). The MALDI spots were rastered in a spiral pattern with a $337 \mathrm{~nm} \mathrm{~N}$ laser firing at $10 \mathrm{~Hz}$ with the laser energy attenuated to an average of $170 \mu \mathrm{J}$ per pulse. The source extraction voltage was set to $1.80 \mathrm{kV}$ with a pulsed dynamic focusing delay of $20 \mu \mathrm{s}$. Pulsed dynamic focusing has shown increased sensitivity over static AP-MALDI by increasing ion transmission efficiency from the ion source into the mass analyzer [38]. All mass spectra were acquired as averages of 10 profiles over an $\mathrm{m} / \mathrm{z}$ range of $500-2000$. Tandem MS was per-

Table 1. Bioinformatic analysis of inherent species-specificity retained in tryptic peptide sequences from plasmid-borne proteins of $B$. anthracis and $B$. thuringiensis

\begin{tabular}{|c|c|c|c|c|c|c|}
\hline B. thuringiensis & cry1Aa & cry1Ab & cry1Ac & cry2Aa & cry2Ab & Total $(\%)$ \\
\hline Unique to toxin & 3 & 3 & 12 & 20 & 18 & 18.1 \\
\hline Unique to $\mathrm{Bt}$ & 54 & 57 & 57 & 33 & 32 & 75.4 \\
\hline Not unique & 21 & 18 & 18 & 7 & 12 & 24.6 \\
\hline Total peptides & 75 & 75 & 75 & 40 & 44 & \\
\hline B. anthracis & \multicolumn{2}{|c|}{ Edema factor } & Lethal factor & \multicolumn{2}{|c|}{ Protective antigen } & Total $(\%)$ \\
\hline Unique to toxin & \multicolumn{2}{|c|}{42} & 43 & \multicolumn{2}{|c|}{32} & 60.3 \\
\hline Unique to $\mathrm{Ba}$ & \multicolumn{2}{|c|}{42} & 43 & \multicolumn{2}{|c|}{32} & 60.3 \\
\hline Not unique & \multicolumn{2}{|c|}{34} & 24 & \multicolumn{2}{|c|}{19} & 39.7 \\
\hline Total peptides & \multicolumn{2}{|c|}{76} & 67 & \multicolumn{2}{|c|}{51} & \\
\hline
\end{tabular}




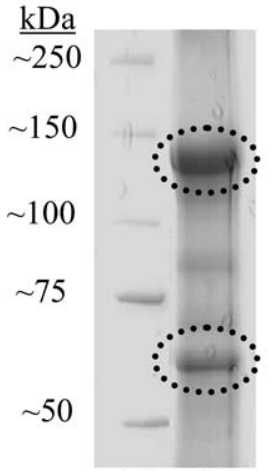

(a) (b)

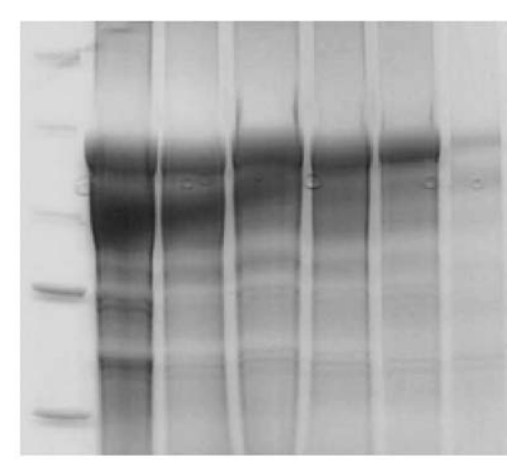

(c) (d) (e) (f) (g) (h) (i)
Figure 1. 1D SDS PAGE of $\delta$-endotoxin solubilization under varying conditions. (a) Protein standards: 50, 75, 100, 150, and $250 \mathrm{kDa}$, (b) solubilization at $\mathrm{pH}=13$, (c) protein standards, (d) solubilization at $\mathrm{pH}=13$ and $65 \mathrm{mM}$ DTT, (e) solubilization at $\mathrm{pH}=12$ and $65 \mathrm{mM}$ DTT, (f) solubilization at $\mathrm{pH}=11$ and 65 $\mathrm{mM}$ DTT, (g) solubilization at $\mathrm{pH}=10$ and $65 \mathrm{mM}$ DTT, (h) solubilization at $\mathrm{pH}=9$ and $65 \mathrm{mM}$ DTT, (i) solubilization at $\mathrm{pH}=8$ and $65 \mathrm{mM}$ DTT. The 130 and $70 \mathrm{kDa}$ bands are circled in lane (b) for reference.

formed on peptides with $m / z$ values that matched those predicted to be unique to $B$. thuringiensis. Precursor ions were selected with an $\mathrm{m} / \mathrm{z}$ window of \pm 1.5 . Selected ions required normalized collision energies of 25-30 (arb. units) for efficient fragment ion production.

\section{MASCOT Searches}

Tryptic peptide masses that matched those of speciesspecific tryptic peptides from $\delta$-endotoxins were isolated in the ion trap and fragmented to obtain sequence information. Tandem MS data were searched against the SwissProt database using the MASCOT MS/MS ion online search engine (www.matrixscience.com) [39]. For all searches, the molecular ion mass tolerance was set to $\pm 1.2 \mathrm{Da}$, fragment ion mass tolerance was set to $\pm 0.6 \mathrm{Da}$, peptide charge was set to +1 , one missed cleavage was allowed, and no restrictions were placed on taxonomy.

\section{Results and Discussion}

\section{Bioinformatics}

As is shown in Table 1 , five $\delta$-endotoxin proteins from B. thuringiensis, Cry1Aa, Cry1Ab, Cry1Ac, Cry2Aa, and $\mathrm{Cry} 2 \mathrm{Ab}$ were digested with trypsin in silico. The resulting tryptic peptides were searched against all entries in the Swiss-Prot/TrEMBL database using MSBLAST [29]. Out of the 309 tryptic peptides analyzed, 233 were found to be unique to $B$. thuringiensis, which represents $75.4 \%$ of the total peptides. This result was very promising and underscores the benefit of targeting this set of proteins for species identification. There was also a high degree of sequence conservation between different $\delta$-endotoxins. Out of the 233 species-specific peptides, only 56 were found to be unique to their individual respective toxins.

An in silico digestion of the three protein toxin components of B. anthracis (lethal factor, edema factor, and protective antigen) was also performed followed by the MS-BLAST exact sequence match search; 117 of the 194 tryptic peptides were found to be unique to their respective toxins and the $B$. anthracis species, which represents $60.3 \%$ of the tryptic peptides from edema factor, lethal factor, and protective antigen. These results further underscore the benefit of focusing on the plasmid-borne protein toxins for Bacillus spore species level identification.

\section{Optimization of $\delta$-Endotoxin Extraction/ Solubilization from B. thuringiensis Spores}

A critical step in developing a rapid proteomics method is the need to selectively solubilize a subset of proteins from the microorganism. Extensive work has been performed by Fenselau et al. that has demonstrated the necessity of selective solubilization $[12,13,40]$. Without this step, the mass spectrometer would likely be saturated with ions resulting in excessive chemical noise. The trypsin digestion would only further compound this problem by generating multiple ions from each protein, and likely lead to a peak at every mass. Therefore, selective solubilization is a critical step that must be applied. The $\delta$-endotoxins of $B$. thuringiensis are soluble under highly alkaline conditions [19, 31, 41]. It was unknown how many other proteins would be soluble under these conditions.

To optimize the efficiency and selectivity of the $\delta$-endotoxins solubilization, the $\mathrm{pH}$ was varied from 8 to 13 with and without $65 \mathrm{mM}$ dithiothreitol (DTT). It was thought that the reducing agent would further aid solubilization by reducing known disulfide bridges within the $\delta$-endotoxin proteins $[41,42]$. After extraction, any remaining spore debris and protein precipitate was removed by centrifugation at $10,000 \times g$ for $3 \mathrm{~min}$. Protein content in the supernatants was monitored by SDS-PAGE. Figure 1 shows a $7.5 \%$ criterion Tris- $\mathrm{HCl}$

Table 2. MASCOT search results summary for in gel protein overnight digestions and the five-minute digestion of the crude $B$. thuringiensis spore protein extract

\begin{tabular}{lcccr}
\hline \multicolumn{1}{c}{ Digestion method } & Protein matches & MASCOT score & Expect value & Species matched \\
\hline \hline In-gel digestion of $\sim 130 \mathrm{kDa}$ band & Cry1Ab & 175 & $1.5 \times 10^{-12}$ & B. thuringiensis \\
In-gel digestion of $\sim 70 \mathrm{kDa}$ band & Cry2Aa & 181 & $3.4 \times 10^{-13}$ & B. thuringiensis \\
5-Min digest of crude spore extract & Cry1Ab & 278 & $7.5 \times 10^{-23}$ & B. thuringiensis \\
\hline
\end{tabular}



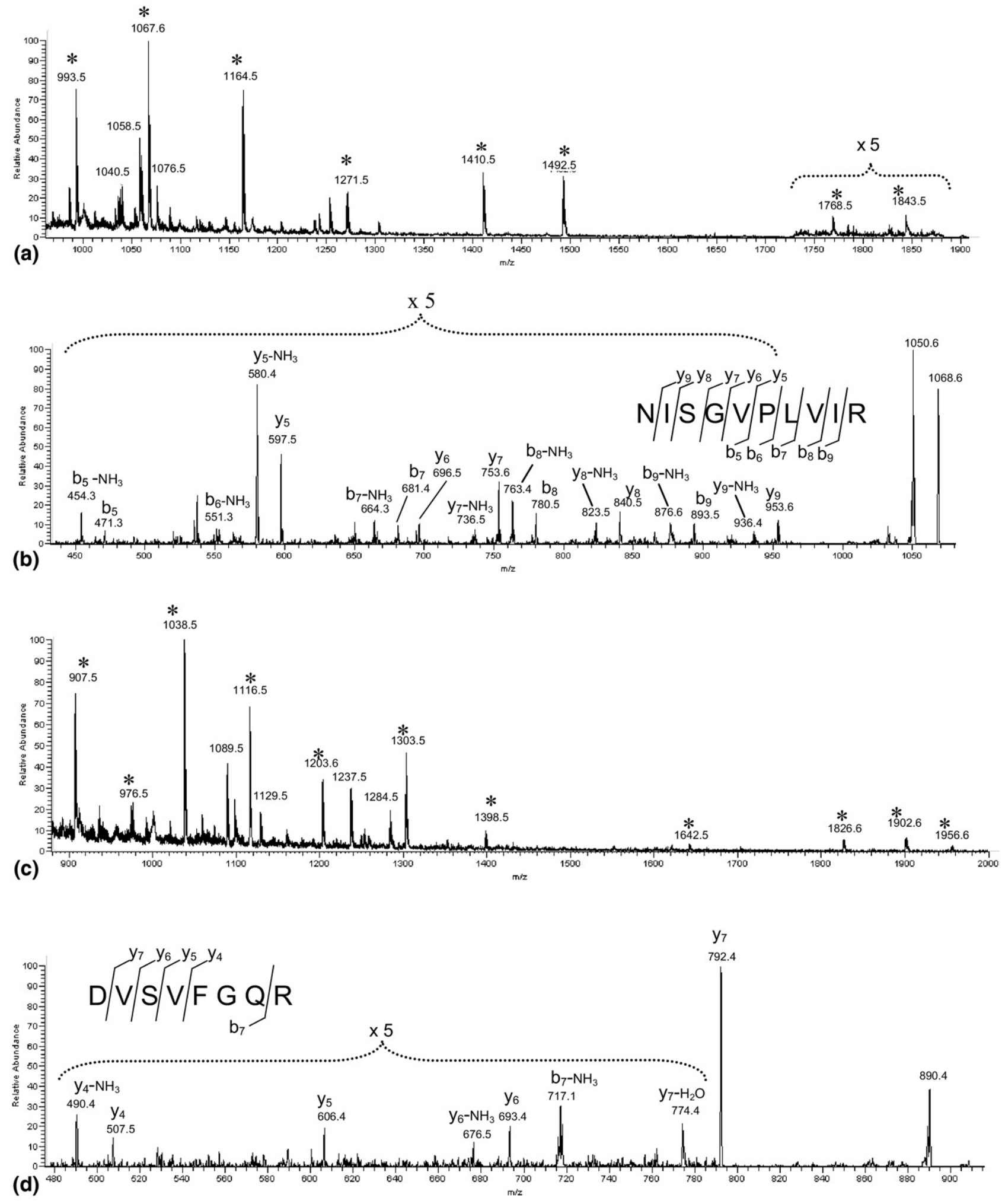

Figure 2. (a) AP-MALDI-MS of in-gel digestion products from $\sim 70 \mathrm{kDa}$ gel band. (b) Tandem MS of $\mathrm{m} / \mathrm{z}$ 1067.6, yielding peptide sequence information. (c) AP-MALDI-MS of in-gel digestion products from $\sim 130 \mathrm{kDa}$ gel band. (d) Tandem MS of $m / z$ 907.5, yielding peptide sequence information. Tryptic peptide mass matches that were specific to $B$. thuringiensis $\delta$-endotoxins, which were selected for tandem MS, are indicated with asterisks in the AP-MALDI-MS spectra. 
gel, which shows that an efficient and highly selective extraction requires a $\mathrm{pH}>12$. Solubilization at $\mathrm{pH}<12$ resulted in minimal or no $\delta$-endotoxin proteins observed (data not shown).

Figure 1 also shows the solubilizations carried out over a $\mathrm{pH}$ range $8-13$ with $65 \mathrm{mM}$ DTT. This result demonstrates the utility of a reducing agent to reduce the $\mathrm{pH}$ required for efficient $\delta$-endotoxin solubilization. However, the DTT solubilized many other proteins, which reduced the selectivity of the method. Consequently, DTT was not pursued further in the development of the rapid method. Lane $b$ of Figure 1 shows two intense bands at $\sim 70$ and $\sim 130 \mathrm{kDa}$ following an extraction at $\mathrm{pH}=13$ without $65 \mathrm{mM}$ DTT. The use of highly alkaline conditions without a reducing agent resulted in an efficient and highly selective solubilization. The $\sim 130 \mathrm{kDa}$ band was suspected to correspond to Cry1Aa, Cry1Ab, and Cry1Ac, while the $\sim 70 \mathrm{kDa}$ band was suspected to correspond to Cry2Aa and $\mathrm{Cry} 2 \mathrm{Ab}$. These assignments were verified by in-gel digestions and AP-MALDI tandem MS. The protein band at $\sim 70 \mathrm{kDa}$ was confirmed to be Cry2Aa (MASCOT score of 181 and expect value of $3.4 \times 10^{-13}$ ). The protein band at $\sim 130 \mathrm{kDa}$ band was confirmed to be Cry1 Ab (MASCOT score of 175 with an expect value of $1.5 \times$ $10^{-12}$ ). These MASCOT results are summarized in Table 2. Figure 2 shows the AP-MALDI mass spectra obtained from these in-gel digests along with representative tandem mass spectra, which contain extensive $b$ and $y$ fragment ions yielding sequence information.

Moving away from a gel based approach to an in solution digestion presented a challenge due to the extremely high $\mathrm{pH}$ required for $\delta$-endotoxin selective solubilization. The alkaline conditions are prohibitive for trypsin digestions, which require a $\mathrm{pH} \sim 8$ for optimum enzymatic activity. Therefore, the $\mathrm{pH}$ must be lowered before the trypsin addition. However, there was concern that adjusting the $\mathrm{pH}$ back down below 9 may result in $\delta$-endotoxin precipitation before the digestions. This concern was tested by performing a basic extraction $(\mathrm{pH}=13)$, followed by $\mathrm{pH}$ reductions to $7-12$. In no case was protein precipitation visually observed. Samples were centrifuged and the supernatants were run on $7.5 \%$ SDS-PAGE to determine whether significant $\delta$-endotoxin protein loss had occurred.

Figure 3 shows this gel, which indicates that over this time scale, the $\delta$-endotoxins remain in solution and accessible for a trypsin digestion. It was surprising to see that the proteins did not precipitate when the $\mathrm{pH}$ was reduced following the solubilization at $\mathrm{pH}=13$. It is reported that increased $\mathrm{pH}$ cleaves alkali-labile interchain disulfide bridges that are critical to $\delta$-endotoxin crystal formation in B. thuringiensis [42]. This severe denaturation appears to persist once the $\mathrm{pH}$ is lowered, leaving the $\delta$-endotoxins in solution; making trypsin digestions possible. These results demonstrate the potential for $\delta$-endotoxins to be selectively solubilized at
$\mathrm{pH}=13$, followed by a $\mathrm{pH}$ reduction down to $\sim 8$ for optimum trypsin activity.

\section{Rapid Method for B. thuringiensis Identification}

B. thuringiensis spores were suspended in $100 \mathrm{mM} \mathrm{KOH}$ $(\mathrm{pH}=13)$, vortexed for $1 \mathrm{~min}$, let sit for $19 \mathrm{~min}$ at room temperature, followed by centrifugation at $10,000 \times g$ for $3 \mathrm{~min}$. The supernatant was removed and the $\mathrm{pH}$ was adjusted to 8 upon drop wise addition of $1 \mathrm{M} \mathrm{HCl}$. A $100 \mu \mathrm{L}$ aliquot of the solubilized protein solution was mixed with $100 \mu \mathrm{L}$ of immobilized trypsin suspended in $100 \mathrm{mM} \mathrm{NH}_{4} \mathrm{HCO}_{3}(\mathrm{pH}=8)$. This mixture was allowed to react for $5 \mathrm{~min}$ at room temperature. The digestion was stopped upon centrifugation at $10,000 \times$ $g$ for $3 \mathrm{~min}$ to remove the immobilized trypsin. A $10 \mu \mathrm{L}$ aliquot of the supernatant was then cleaned up with a $\mu \mathrm{C}-18$ Ziptip and $1 \mu \mathrm{L}$ was then spotted on the APMALDI plate for analysis. Figure 4a shows the APMALDI mass spectrum of the peptide products from the 5-min trypsin digestion. Those $\mathrm{m} / \mathrm{z}$ values marked with asterisks matched species-specific peptides from $B$. thuringiensis $\delta$-endotoxins. These peaks were subjected to tandem mass spectrometry in the linear ion trap.

It was surprising that $\mathrm{Cry} 1 \mathrm{Ab}$ tryptic peptides dominated the mass spectrum from the rapid digestion. Only one Cry2Aa tryptic peptide was observed at $\mathrm{m} / \mathrm{z}$ 1492.5, while 16 tryptic peptides from Cry1 Ab were observed. However, upon inspection of the gel of the $\delta$-endotoxins following basic solubilization (Figure 1, lane b), the intensity of the $130 \mathrm{kDa}$ band $(\mathrm{Cry} 1 \mathrm{Ab})$ appears greater than that of the $70 \mathrm{kDa}$ band (Cry2Aa). It is speculated that this concentration difference resulted in significant ion suppression at the peptide level following the rapid digestion of the $\delta$-endotoxin mixture. It is also worth noting that while other proteins were observed in the gels following basic extraction,

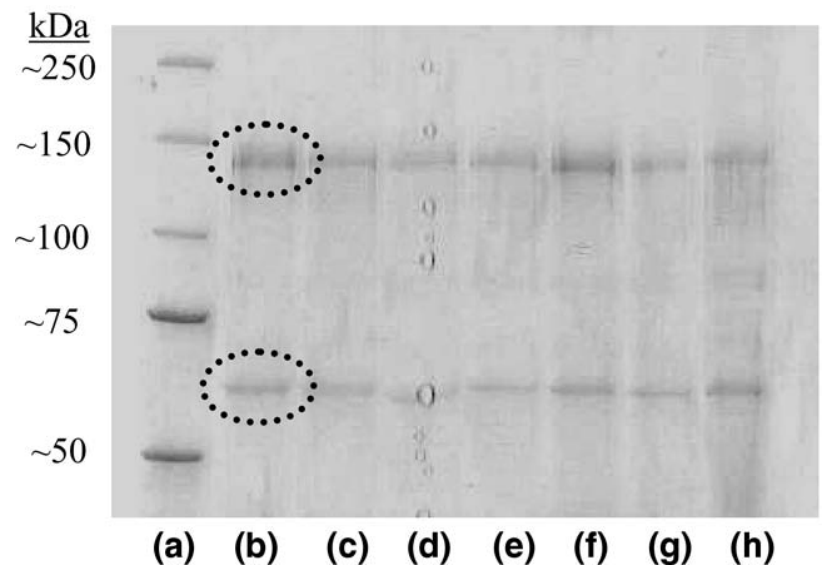

Figure 3. 1D SDS-PAGE of $\delta$-endotoxins extracted at $\mathrm{pH} 13$ and then adjusted to $\mathrm{pH}$ values of (c) 12, (d) $11,(\mathbf{e}) 10,(\mathbf{f}) 9,(\mathrm{~g}) 8$, (h) 7. Lane (a) is a set of protein standards: $50,75,100,150$, and 250 $\mathrm{kDa}$. Lane (b) is a control in which the extraction was done at $\mathrm{pH}=13$ and the $\mathrm{pH}$ was left unchanged. The 130 and $70 \mathrm{kDa}$ bands are circled in lane (b) for reference. 
(a)
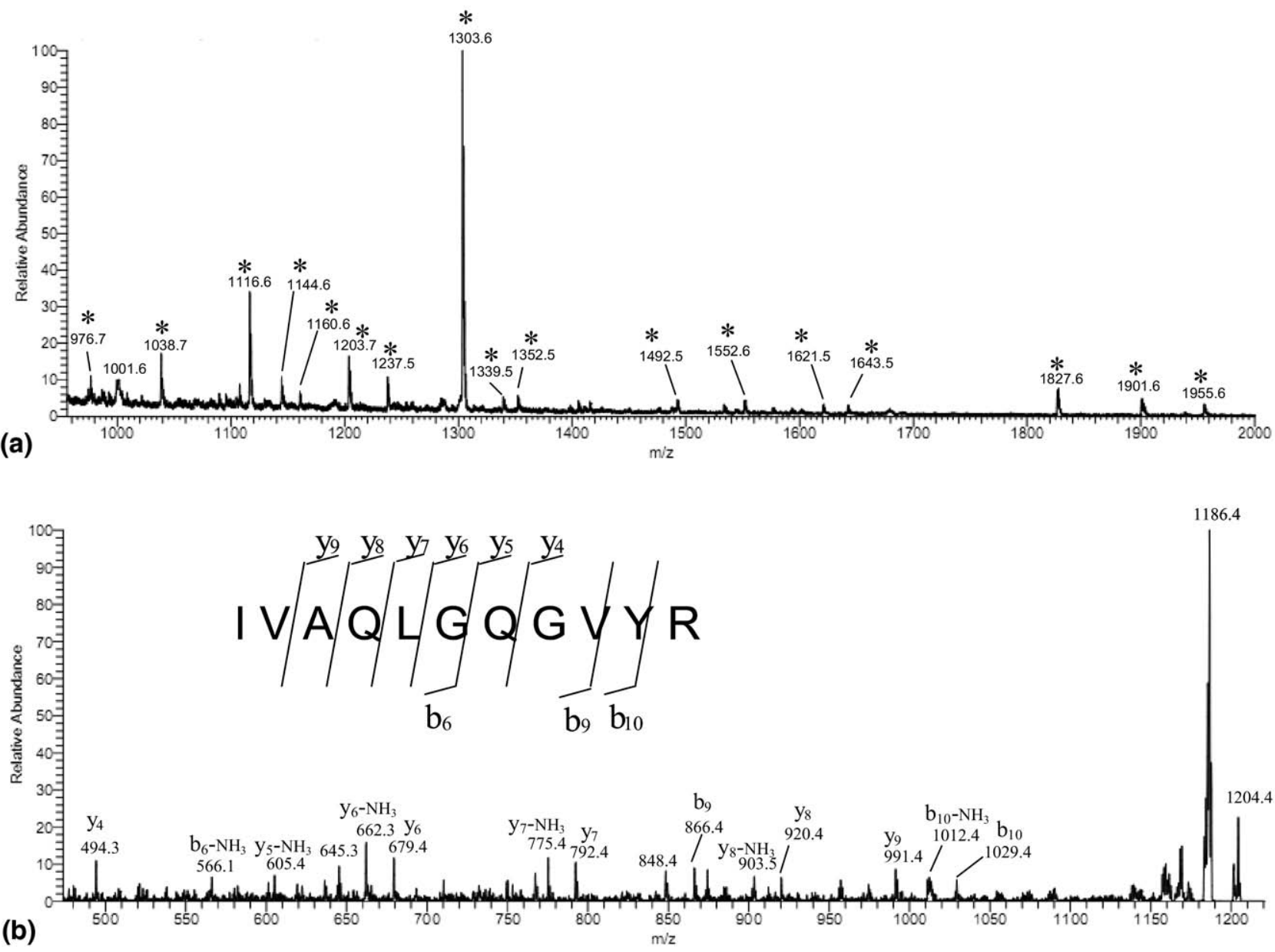

Figure 4. (a) AP-MALDI mass spectrum of peptide products resulting from a basic solubilization of $\delta$-endotoxin proteins directly from $B$. thuringiensis spores followed by a 5-min trypsin digestion. Tryptic peptide mass matches to those from $\delta$-endotoxins are indicated with asterisks. (b) Tandem mass spectrum of $\mathrm{m} / \mathrm{z} 1203.7$ yielding peptide sequence information.

none was identified in the rapid digestion, likely due to suppression by the Cry1 Ab tryptic peptides.

Figure $4 \mathrm{~b}$ shows a representative tandem mass spectrum of $m / z$ 1203.7, which yielded significant sequence information due to the series of $\mathrm{y}$ and $\mathrm{b}$ ions observed. All tandem mass spectra data obtained were pooled and searched against all entries in the SwissProt/ Trembl database using the MASCOT MS/MS ion search engine without taxonomic restriction [39]. This search resulted in a definitive protein match to the $133 \mathrm{kDa}$ protein $\mathrm{Cry} 1 \mathrm{Ab}$ with a MASCOT score of 278 and expect value of $7.5 \times 10^{-23}$.

This MASCOT score is relatively high and illustrates the advantage of targeting masses matching speciesspecific peptides for tandem MS analysis. One would expect a much lower MASCOT score if all peptides observed were analyzed without any bioinformatic selection process. As with the in-gel digestions, this protein match was unique to $B$. thuringiensis, thereby demonstrating species level specificity following only a 5 min trypsin digestion. Surprisingly this result exceeded those achieved by the in-gel digestions (Table 2; also see Supplemental Materials, which can be found in the electronic version of this article). It is speculated that this is due to sample loss during the multiple steps of the in-gel digestion protocol, which did not occur in the rapid digestion method.

\section{Conclusions}

To date, MALDI-MS proteomics methods focused on $B$. anthracis detection have targeted chromosomally encoded proteins [13-15]. Unfortunately, nearly all chromosomally encoded proteins of $B$. anthracis have high sequence conservation between closely related species (B. anthracis, B. thuringiensis, and B. cereus), which hinders species-level identification. However, these species harbor entirely different plasmids, which encode different protein toxins. By targeting these plasmidborne proteins, species-level identification can be realized by MALDI-MS. A proteomics AP-MALDI-MS method has demonstrated species-level identification of $B$. thuringiensis by targeting species-specific tryptic peptides from $\delta$-endotoxin proteins. Species-specific pep- 
tides were identified using in silico trypsin digestions and BLAST exact peptide sequence searches.

A total of $75.4 \%$ of the tryptic peptides from plasmid-borne $\delta$-endotoxins of $B$. thuringiensis were found to be species-specific. Similarly, $60.3 \%$ of the tryptic peptides from the plasmid-borne protein toxins of $B$. anthracis were found to be species-specific. This high level of uniqueness made these plasmid-borne proteins attractive analytical targets for species identification. A basic selective solubilization of $\delta$-endotoxins directly from $B$. thuringiensis spores was optimized by a conventional SDS-PAGE analysis. Protein bands observed at $\sim 70$ and $\sim 130 \mathrm{kDa}$ were excised, digested with trypsin, and identified by AP-MALDI-MS/MS. The $\sim 70$ and $\sim 130 \mathrm{kDa}$ proteins were confirmed to be Cry2Aa and Cry1 $\mathrm{Ab}$, respectively, both of which originate from $B$. thuringiensis.

The rapid method that was developed required a 5 min trypsin digestion followed by direct AP-MALDIMS/MS analysis without the need for gel electrophoresis. This rapid method produced a definitive identification of the $\sim 130 \mathrm{kDa} \delta$-endotoxin matching Cry1 Ab with a MASCOT score of 278 and expect value of $7.5 \times$ $10^{-23}$. These results demonstrate the ability AP-MALDI-MS to detect and identify $B$. thuringiensis spores at the species level following a 5-min trypsin digestion. This study further underscores the advantage of performing a bioinformatics evaluation to focus experimental efforts on highly specific biomarkers before performing the MALDI-MS analysis. Future efforts will focus on an on-probe protocol and application of the method to food products such as B. thuringiensis corn.

\section{Acknowledgments}

The authors gratefully acknowledge financial support from a California State University Program for Education and Research in Biotechnology Seed grant for 2008-2009, a Naraghi Research Award for 2008-2009, and Research Scholarship and Creative Activity grants from 2006-2009.

\section{Appendix A Supplementary Material}

Supplementary material associated with this article may be found in the online version at doi:10.1016/ j.jasms.2010.01.032.

\section{References}

1. Anthrax: What You Need to Know. Center for Disease Control and Prevention 2003.

2. Meselson, M.; Guillemin, J.; Hugh-Jones, M.; Langmuir, A.; Popova, I.; Shelokov, A.; Yampolskaya, O. The Sverdlovsk Anthrax Outbreak of 1979. Science 1994, 266, 1202-1208

3. Keim, P.; Smith, K.; Keys, C.; Takahashi, H.; Kurata, T.; Kaufmann, A. Molecular Investigation of the Aum Shinrikyo Anthrax Release in Kameido, Japan. J. Clin. Microbiol. 2001, 39, 4566-4567.

4. Enserink, M. This Time It was Real: Knowledge of Anthrax Put to the Test. Science 2001, 294, 490-491.

5. Ecker, D. J.; Sampath, R.; Blyn, L. B.; Eshoo, M. W.; Ivy, C.; Ecker, J. A.; Libby, B.; Samant, V.; Sannes-Lowery, K. A.; Melton, R. E.; Russell, K.; Freed, N.; Barrozo, C.; Wu, J. G.; Rudnick, K.; Desai, A.; Moradi, E.; Knize, D. J.; Robbins, D. W.; Hannis, J. C.; Harrell, P. M.;
Massire, C.; Hall, T. A.; Jiang, Y.; Ranken, R.; Drader, J. J.; White, N.; McNeil, J. A.; Crooke, S. T.; Hofstadler, S. A. Rapid Identification and Strain-Typing of Respiratory Pathogens for Epidemic Surveillance. Proc. Natl. Acad. Sci. U.S.A. 2005, 102, 8012-8017.

6. Mackay, I. M. Real-time PCR in the Microbiology Laboratory. Clin. Microbiol. Infect. 2004, 10, 190-212.

7. Rodriguez-Lazaro, D.; D'Agostino, M.; Herrewegh, A.; Pla, M.; Cook, N.; Ikonomopoulos, J. Real-Time PCR-Based Methods for Detection of Mycobacterium Avium Subsp. Paratuberculosis in Water and Milk. Int. J. Food Microbiol. 2005, 101, 93-104.

8. Liu, C.; Hofstadler, S. A.; Bresson, J. A.; Udseth, H. R.; Tsukuda, T.; Smith, R. D.; Snyder, A. P. On-Line Dual Microdialysis with ESI-MS for Direct Analysis of Complex Biological Samples and Microorganism Lysates. Anal. Chem. 1998, 70, 1797-1801.

9. Xiang, F.; Anderson, G. A.; Veenstra, T. D.; Lipton, M. S.; Smith, R. D. Characterization of Microorganisms and Biomarker Development from Global ESI-MS/MS Analyses of Cell Lysates. Anal. Chem. 2000, 72, 2475-2481.

10. Cargile, B. J.; McLuckey, S. A.; Stephenson, J. L. Identification of Bacteriophage MS2 Coat Protein from E. coli Lysates Via Ion Trap Collisional Activation of Intact Protein Ions. Anal. Chem. 2001, 73, $1277-1285$.

11. Demirev, P. A.; Lin, J. S.; Pineda, F. J.; Fenselau, C. Bioinformatics and Mass Spectrometry for Microorganism Identification: Proteome-Wide Post-Translational Modifications and Database Search Algorithms for Characterization of Intact H. Pylori. Anal. Chem. 2001, 73, 4566-4573.

12. Fenselau, C.; Demirev, P. A. Characterization of Intact Microorganisms by MALDI Mass Spectrometry. Mass Spectrom. Rev. 2001, 20, 157-171.

13. Warscheid, B.; Fenselau, C. Characterization of Bacillus Spore Species and Their Mixtures Using Postsource Decay with a Curved-Field Reflectron. Anal. Chem. 2003, 75, 5618-5627.

14. Hathout, Y.; Setlow, B.; Cabrera-Martinez, R.; Fenselau, C.; Setlow, P. Small, Acid-Soluble Proteins as Biomarkers in Mass Spectrometry Analysis of Bacillus Spores. Appl. Environ. Microbiol. 2003, 69, 1100-1107.

15. Pribil, P.; Patton, E.; Black, G.; Doroshenko, V.; Fenselau, C. Rapid Characterization of Bacillus Spores Targeting Species-Unique Peptides Produced with an Atmospheric Pressure Matrix-Assisted Laser Desorption/Ionization Source. J. Mass Spectrom. 2005, 40, 464-474.

16. Helgason, E.; Okstad, O. A.; Caugant, D. A.; Johansen, H. A.; Fouet, A.; Mock, M.; Hegna, I.; Kolsto, A.-B. Bacillus anthracis, Bacillus cereus, and Bacillus thuringiensis: One Species on the Basis of Genetic Evidence. Appl. Environ. Microbiol. 2000, 66, 2627-2630.

17. Granum, P. E.; Lund, T. Bacillus cereus and Its Food Poisoning Toxins. FEMS Microbiol. Lett. 1997, 157, 223-228.

18. Brossier, F.; Mock, M. Toxins of Bacillus anthracis. Toxicon 2001, 39, 1747-1755.

19. Lee, K. Y. Mass Spectrometric Sequencing of Endotoxin Proteins of Bacillus thuringiensis ssp. konkukian Extracted from Polyacrylamide Gels. Proteomics 2006, 6, 1512-1517.

20. Doroshenko, V. M.; Laiko, V. V.; Taranenko, N. I.; Berkout, V. D.; Lee, H. S. Recent Developments in Atmospheric Pressure MALDI Mass Spectrometry. Int. J. Mass Spectrom. 2002, 221, 39-58.

21. Madonna, A. J.; Voorhees, K. J.; Taranenko, N. I.; Laiko, V. V.; Doroshenko, V. M. Detection of Cyclic Lipopeptide Biomarkers from Bacillus Species Using Atmospheric Pressure Matrix-Assisted Laser Desorption/Ionization Mass Spectrometry. Anal. Chem. 2003, 75, 1628-1637.

22. Laiko, V. V.; Moyer, S. C.; Cotter, R. J. Atmospheric Pressure MALDI/ Ion Trap Mass Spectrometry. Anal. Chem. 2000, 72, 5239-5243.

23. Laiko, V. V.; Baldwin, M. A.; Burlingame, A. L. Atmospheric Pressure Matrix-Assisted Laser Desorption/Ionization Mass Spectrometry. Anal. Chem. 2000, 72, 652-657.

24. Eizaguirre, M.; Tort, S.; pez, C.; Albajes, R. Effects of Sublethal Concentrations of Bacillus thuringiensis on Larval Development of Sesamia nonagrioides. J. Econ. Entomol. 2005, 98, 464-470.

25. Bechtel, D. B.; Bulla, L. A. Electron Microscope Study of Sporulation and Parasporal Crystal Formation in Bacillus thuringiensis. J. Bacteriol. 1976, 127, 1472-1481.

26. VanderNoot, V. A.; Branda, S.; Jokerst, A.; Gaucher, S.; Lane, T. W. Rapid Onsite Assessment of Spore Viability. Sandia National Laboratories Research Report. 2005, SAND2005/7326, 1-27.

27. Sirard, J. C.; Mock, M.; Fouet, A. The Three Bacillus anthracis Toxin Genes are Coordinately Regulated by Bicarbonate and Temperature. J. Bacteriol. 1994, 176, 5188-5192.

28. Leppla, S. H. Production and Purification of Anthrax Toxin. Methods Enzymol. 1988, 165, 103-116.

29. Shevchenko, A.; Sunyaev, S.; Loboda, A.; Shevchenko, A.; Bork, P.; Ens, W.; Standing, K. G. Charting the Proteomes of Organisms with Unsequenced Genomes by MALDI-Quadrupole Time-of-Flight Mass Spectrometry and BLAST Homology Searching. Anal. Chem. 2001, 73, 1917-1926.

30. USDHHS; CDC\&P; NIH Biosafety in Microbiological and Biomedical Laboratories $(B M B L)$ 1999, 4

31. Tyrell, D. J.; Bulla, L. A. Jr.; Andrews, R. E. Jr.; Kramer, K. J.; Davidson, L. I.; Nordin, P. Comparative Biochemistry of Entomocidal Parasporal Crystals of Selected Bacillus thuringiensis Strains. J. Bacteriol. 1981, 145, 1052-1062. 
32. Garfin, D. E.; Murray, P. D. In Methods in Enzymology, Vol. CLXXXII; Academic Press: 1990; p. 425-441.

33. Laemmli, U. K. Cleavage of Structural Proteins During the Assembly of the Head of Bacteriophage T4. Nature 1970, 227, 680-685.

34. Rosenfeld, J.; Capdevielle, J.; Guillemot, J. C.; Ferrara, P. In-Gel Digestion of Proteins for Internal Sequence Analysis After One- or TwoDimensional Gel Electrophoresis. Anal. Biochem. 1992, 203, 173-179.

35. Agaisse, H.; Lereclus, D. How Does Bacillus thuringiensis Produce so Much Insecticidal Crystal Protein? J. Bacteriol. 1995, 177, 6027-6032.

36. Andrews, R. E. Jr.; Iandolo, J. J.; Campbell, B. S.; Davidson, L. I.; Bulla, L. A. Jr. Rocket Immunoelectrophoresis of the Entomocidal Parasporal Crystal of Bacillus thuringiensis Subsp. Kurstaki. Appl. Environ. Microbiol. 1980, 40, 897-900.

37. Vestling, M. M.; Murphy, C. M.; Fenselau, C. Recognition of Trypsin Autolysis Products by High-Performance Liquid Chromatography and Mass Spectrometry. Anal. Chem. 1990, 62, 2391-2394.
38. Tan, P. V.; Laiko, V. V.; Doroshenko, V. M. Atmospheric Pressure MALDI with Pulsed Dynamic Focusing for High-Efficiency Transmission of Ions into a Mass Spectrometer. Anal. Chem. 2004, 76, 2462-2469. 39. Perkins, D. N.; Pappin, D. J. C.; Creasy, D. M.; Cottrell, J. S. ProbabilityBased Protein Identification by Searching Sequence Databases Using Mass Spectrometry Data. Electrophoresis 1999, 20, 3551-3567.

40. Demirev, P. A.; Fenselau, C. Mass Spectrometry for Rapid Characterization of Microorganisms. Annu. Rev. Anal. Chem. 2008, 1, 71-93.

41. Du, C.; Martin, P. A. W.; Nickerson, K. W. Comparison of Disulfide Contents and Solubility at Alkaline $\mathrm{pH}$ of Insecticidal and Noninsecticidal Bacillus thuringiensis Protein Crystals. Appl. Environ. Microbiol. 1994, 60, 3847-3853.

42. Bietlot, H. P.; Vishnubhatla, I.; Carey, P. R.; Pozsgay, M.; Kaplan, H. Characterization of the Cysteine Residues and Disulphide Linkages in the Protein Crystal of Bacillus thuringiensis. Biochem. J. 1990, 267, 309-315. 